\title{
PERANAN BADAN PERMUSYAWARATAN DESA DALAM PEMBERDAYAAN MASYARAKAT DI SIDOARJO
}

\author{
Risaatul Lailiyah \\ Notaris Priswiari Tur Pramesti, SH. M.Kn., Jl. Mayjend Sungkono No. I I - 12 Sidoarjo \\ | risaatullailiyah@ymail.com
}

\begin{abstract}
This paper describes about the role of the Village Consultative Assembly in village of Jati, Banjar Bendo, and Sumput of Sidoarjo regency in empowering the community. Village Consultative Assembly is an institution that is the embodiment of democracy in a village's governance as an administrative element of the village. It functionates to set rules together with the Head of the village and accommodates the aspirations of the people. Village Consultative Assembly's role in empowering the community in the village of Jati and Sumput are less active. While, the Village Consultative Assembly in Banjar Bendo is very active. Beeing active or not active in carrying out their role lies on the implementation of the legislative's function that has been defined by Peraturan Pemerintah No. 72 year 2005 article 35 Juncto PERDA (Regional Legislation) of Sidoarjo No. 07 year 2006 article 12. The legislative duties and functions of the Village Consultative Assembly in Sidoarjo can not run optimally. This is indicated by the Village Consultative Assembly's less comprehensive in Jati and Sumput in framing the conventional regulations into the written rules. It is so since they got less technical assistance from the local government, especially in the field of legislation.
\end{abstract}

Keywords: Role, village consultative assembly, Sidoarjo.

Abstrak: Tulisan ini menjelaskan tentang peranan Badan Permusyawaratan Desa (BPD) desa Jati, desa Banjar Bendo dan desa Sumput kecamatan Sidoarjo dalam memberdayakan masyarakat. Badan Permusyawaratan Desa (BPD) adalah lembaga yang merupakan perwujudan demokrasi dalam penyelenggaraan pemerintahan desa sebagai unsur penyelenggara pemerintahan desa. BPD berfungsi menetapkan peraturan desa bersama Kepala desa, serta menampung dan menyalurkan aspirasi masyarakat. Peranan BPD dalam 
memberdayakan masyarakat di desa Jati kurang aktif, BPD Desa Banjar Bendo sangat aktif dan BPD Desa Sumput kurang aktif. Kurang aktifnya dalam menjalankan perannya terletak pada pelaksanaan fungsi legislasi yang telah ditetapkan oleh PP Nomor 72 Tahun 2005 pasal 35 Juncto PERDA Sidoarjo Nomor 07 Tahun 2006 pasal 12. Tugas dan fungsi legislasi BPD di desa Kecamatan Sidoarjo belum dapat berjalan secara maksimal, hal ini ditunjukan dengan kurang komprehensif-nya BPD di Desa Jati dan Desa Sumput Kecamatan Sidoarjo di dalam membingkai peraturan-peraturan desa yang masih bersifat konvensional ke bentuk peraturan tertulis serta kurangnya bimbingan teknis dari Pemerintah Daerah khususnya dalam bidang legislasi.

Kata Kunci: Peranan, Badan Permusyawaratan Desa, Sidoarjo.

\section{Pendahuluan}

Pemerintahan daerah Kabupaten/Kota dibentuk pemerintahan desa yang terdiri dari pemerintah desa dan Badan Permusyawaratan Desa. ${ }^{1}$ Sesuai pasal 216 ayat (1) UndangUndang Nomor 32 Tahun 2004 tentang Pemerintahan Daerah perlu ditetapkan Peraturan Pemerintah Nomor 72 Tahun 2005 tentang Desa. Dalam PP Nomor 72 Tahun 2005 tentang Desa, pasal-pasal yang menyebutkan tentang Badan Permusyawaratan Desa itu tercantum dalam pasal 29 s/d 42.

Peraturan Pemerintah Republik Indonesia No. 72 Tahun 2005 tentang Desa dalam Pasal 1 ayat (5) menjelaskan bahwa: "Desa merupakan kesatuan masyarakat hukum yang memiliki batasbatas wilayah yang berwenang untuk mengatur dan mengurus kepentingan masyarakat setempat, berdasarkan asal-usul dan adat-istiadat setempat yang diakui dan dihormati dalam sistem Pemerintahan Negara Kesatuan Republik Indonesia".

Pada era otonomi daerah, dipandang perlu penguatan lembaga-lembaga desa serta penguatan organisasi-organisasi masyarakat sipil dalam penyelenggaraan Pemerintahan Desa, supaya ada pembatasan dominasi kepala desa dalam 
penyelenggaraan pemerintah di desa. ${ }^{2}$ Dalam melaksanakan pasal 42 PP Nomor 72 Tahun 2005 tentang Desa, maka perlu ditetapkan Peraturan Daerah yang menjalankan Peraturan Pemerintah tersebut. Sesuai judul yang penulis ambil yaitu tentang peranan Badan Permusyawaratan Desa dalam pemberdayaan masyarakat desa Kecamatan Sidoarjo, maka yang menjadi dasarnya yaitu PERDA Sidoarjo Nomor 07 Tahun 2006 tentang Badan Permusyawaratan Desa.

Pasal 1 huruf (e) PERDA Sidoarjo Nomor 07 Tahun 2006 Tentang Badan Permusyawaratan Desa menjelaskan, bahwa: “Badan Permusyawaratan Desa (BPD) atau yang disebut dengan nama lain adalah lembaga yang merupakan perwujudan demokrasi dalam penyelenggaraan pemerintahan desa sebagai unsur penyelenggara pemerintahan desa". BPD berfungsi menetapkan peraturan desa bersama Kepala Desa seta menampung dan menyalurkan aspirasi masyarakat". ${ }^{3}$ Kedua fungsi Badan Permusyawaratan Desa tersebut merupakan sarana penting bagi pelembagaan partisipasi masyarakat dalam proses pembangunan desa serta sebagai wadah untuk memberdayakan aspirasi masyarakat.

Badan Permusyawaratan Desa merupakan bentuk sektor publik yang berbentuk badan pemerintahan. Dengan adanya BPD diharapkan terjalin hubungan yang sinergis antara BPD sebagai representasi dari masyarakat desa dengan Kepala desa sebagai kepala pemerintahan desa. Karena masyarakat memiliki wadah untuk menyampaikan aspirasi. Sehingga kepentingan rakyat dapat terakomodir dalam perumusan peraturan desa. ${ }^{4}$

${ }^{2}$ Walhi, "Perdes (Penting bagi Masyarakat dalam Menentukan Arah Pembanguna Desa)", dalam http://wnw.walhibengkulu.org/2009/06/perdes-penting-bagi-masyarakat dalam.html, (I6 Maret 2013).

${ }^{3}$ Lihat Pasal 34 Peraturan Pemerintah Nomor 72 Tahun 2005 Juncto Pasal I I Peraturan Daerah Sidoarjo Nomor 07 Tahun 2006.

${ }^{4}$ Nuraida Muji Kurnia, "Peran Badan Permusyawaratan Desa (BPD) Sebagai Organisasi Sektor Publik", dalam http://djangka.com/2013/0I/24/peran-badan-permusyawaratan- desa-bpdsebagai organisasi-sektor-publik/, ( 6 Maret 20।3). 
Sesuai dengan konteks Islam, bentuk pemerintah dalam tata negara Islam adalah aparatur atau institusi yang diberi wewenang dan kepercayaan oleh rakyat melalui pemilihan yang jujur dan adil untuk melaksanakan dan menegakkan peraturan dan undangundang yang telah dibuat. ${ }^{5}$ Di dalam sejarah pemerintahan Islam, elemen yang pokok dalam demokrasi adalah aplikasi sistem shûrâ. Shûrâ merupakan suatu prinsip tentang cara pengambilan keputusan yang secara eksplisit ditegaskan dalam al-Qur'an. Misalnya saja disebut dalam Surat Ali Imran: 159:
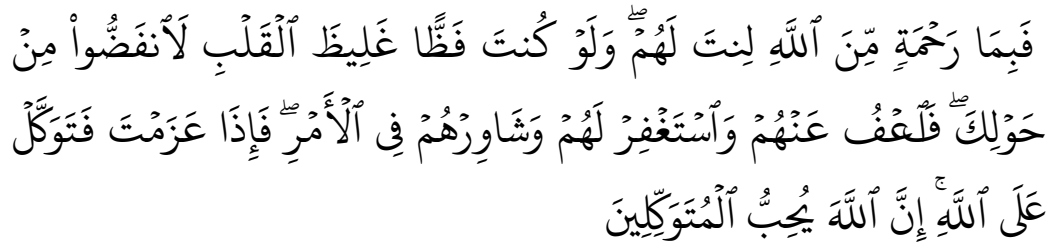

"Maka disebabkan rahmat dari Allah-lah kamu berlaku lemahlembut terhadap mereka. Sekiranya kamu bersikap keras lagi berhati kasar, tentulah mereka menjauhkan diri dari sekelilingmu. Karena itu maafkanlah mereka, mohonkanlah ampun bagi mereka, dan bermusyawarahlah dengan mereka dalam urusan itu. Kemudian apabila kamu telah membulatkan tekad, maka bertawakallah kepada Allah. Sesungguhnya Allah menyukai orang-orang yang bertawakal kepadaNya." (QS. Ali Imran: 159)6

Musyawarah dapat diartikan sebagai suatu forum tukarmenukar pikiran, gagasan atau ide, termasuk saran-saran yang diajukan dalam memecahkan masalah sebelum tiba dalam mengambil putusan yang bertujuan untuk mencegah lahirnya suatu keputusan yang merugikan kepentingan umum atau kepentingan masyarakat. Dalam praktik kehidupan umat Islam, lembaga yang paling dikenal sebagai pelaksana shura adalah ahl al-

5 Muhammad Iqbal, Fiqih Siyasah: Kontekstualisasi Doktrin Politik Islam, (Jakarta: Gaya Media, $2001), 138$.

${ }^{6}$ Departemen agama RI, Al-Qur'an Terjemah al- Jumatul Ali, (Bandung: CV Penerbit J-ART, 2005), 72. 
hall wa al-'aqd pada zaman Khulafaurrasyidin. ${ }^{7}$ Ahl al-hall wa al-'aqd ada dalam sistem pemerintahan Islam dikarenakan adanya suatu perintah dalam al-Qur'an untuk bermusyawarah. Lembaga ini lebih menyerupai tim formatur yang bertugas memilih kepala negara atau khalifah. ${ }^{8}$

Ahl al-hall wa al-'aqd merupakan lembaga perwakilan yang menampung dan menyalurkan aspirasi atau suara masyarakat. Anggotanya berasal dari orang-orang yang berasal dari berbagai kalangan yang terdiri dari ulama, para pemimpin suku dan pemuka masyarakat. Mereka juga bertugas menetapkan dan mengangkat kepala negara sebagai pemimpin pemerintah. Namun semuanya mengacu pada pengertian "Sekelompok anggota masyarakat yang mewakili umat (rakyat) dalam menentukan arah dan kebijaksanaan pemerintahan demi tercapainya kemaslahatan hidup mereka" 9 .

Adapun penjelasan dalam al-Qur'an dan Hadis, tidak terdapat istilah ahl al-hall wa al-'aqd. Istilah tersebut hanya terdapat dalam kitab-kitab fiqh siyasah, sebab para ulama fiqh siyasah, meliputi Imam al-Mawardi, Ibnu Taimiyah, al-Baghdadi, dan al-Maududi, melihat ahl al-hall wa al-'aqd mempunyai kesamaan dengan makna uli al-amr yang terdapat di surat al-Nisa' ayat 59, yang berbunyi:
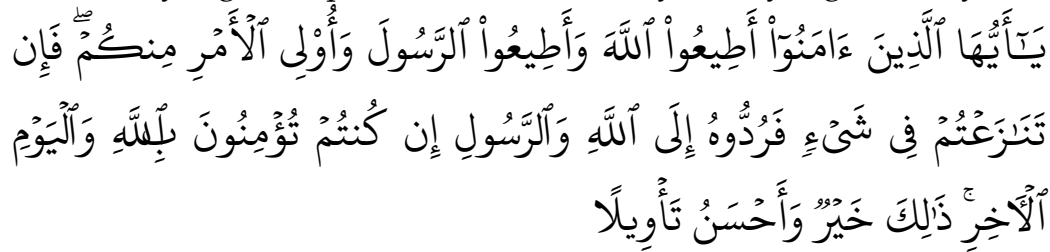

"Hai orang-orang yang beriman taatilah Allah dan taatilah RasulNya, dan ulil amri diantara kamu, kemudian jika kamu berlainan pendapat tentang sesuatu maka kembalikanlah ia kepada Allah (AlQur'an) dan Rasul (sunnahnya), jika kamu benar-benar beriman kepada

${ }^{7}$ Farid Abdul Khaliq, Fikih Politik Islam, (Jakarta: AMZAH, 2005), 78.

${ }^{8}$ Sariono, "Ahl al-Hall wa al-'Aqd", dalam http://refrensiagama.com/20। I/0 I/ahl-al-hall-wa-alaqd.htm, (I 6 Maret 2013).

${ }^{9}$ Muhammad lqbal, Fiqh Siyasah: Konstektual Doktrin Politik Islam, I37-I38.

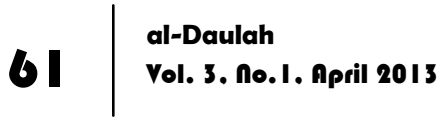


Allah dan hari kemudian. Yang demikian itu lebih utama (bagimu) dan lebih baik akibatnya." (QS. al-Nisa': 59).10

Shûrâ merupakan proses musyawarah yang mengatur para pemimpin Islam, yang memang diperintahkan untuk memperhatikan hasil yang dicapai dari pengambilan keputusan yang akan mempengaruhi kepentingan rakyat, apabila memang tidak ada perintah yang jelas di dalam al-Qur'an, hadis, ataupun ijma' para sarjana muslim yang berkaitan dengan masalah khusus. ${ }^{11}$

Uraian di atas dapat ditarik pertanyaan, bagaimanakah peranan Badan Permusyawaratan Desa dalam pemberdayaan masyarakat desa Kecamatan Sidoarjo menurut PP Nomor 72 Tahun 2005 Tentang Desa Juncto PERDA Sidoarjo Nomor 07 Tahun 2006 Tentang Badan Permusyawaratan Desa serta ditinjau dari perspektif figh siyasah.

Peranan BPD dalam Pemberdayaan Masyarakat Desa Kecamatan Sidoarjo Menurut PP No. 72 Tahun 2005 Juncto PERDA Sidoarjo Nomor 07 Tahun 2006

Badan Permusyawaratan Desa (BPD) atau yang disebut dengan nama lain adalah lembaga yang merupakan perwujudan demokrasi dalam penyelenggaraan pemerintahan desa sebagai unsur penyelenggara pemerintahan desa. Pengertian tersebut tercantum dalam pasal 1 ayat (8) PP Nomor 72 Tahun 2005 tentang Desa Juncto pasal 1 huruf (e) PERDA Sidoarjo Nomor 07 Tahun 2006 tentang Badan Permusyawaratan Desa.

Badan Permusyawaratan Desa merupakan salah satu unsur penyelenggara pemerintahan desa dan merupakan perwujudan demokrasi dalam pemerintahan di tingkat desa. Sehingga, anggota BPD harus dipilih oleh masyarakat melalui musyawarah dan

\footnotetext{
${ }^{10}$ Departemen agama RI, Al-Qur'an Terjemah al- Jumatul Ali; 88

" Muhammad al- Buraey, Penerjemah: Ahmad Nashir Budiman, Islam: Landasan Alternatif Administrasi Pembangunan, (Jakarta: Rajawali, 1986), 346
} 
mufakat. Anggota BPD terdiri dari unsur Rukun Tetangga, Rukun Warga, golongan profesi dan tokoh masyarakat.

Pemilihan anggota BPD ini dilaksanakan oleh angota BPD yang masih bersama pemerintah desa untuk membenuk panitia pemilihan anggota BPD yang baru 3 bulan sebelum habis masa jabatan BPD yang lama. Panitia pembentukan ini terdiri dari ketua RT, ketua RW dan tokoh masyarakat. Panitia pembentukan BPD ini bertugas melaksanakan pemilihan anggota BPD dengan sistem penjaringan dan penyaringan calon anggota BPD sesuai dingan tingkatannya yang nantinya akan diajukan di tingkat desa melalui musyawarah dan mufakat bersama masyarakat setempat.

Mekanisme musyawarah dan mufakat dalam pemilihan calon anggota BPD ini dilakukan secara bertingkat, meliputi:12

a. Musyawarah di tingkat Rukun Tetangga (RT) dengan melibatkan seluruh kepala keluarga serta tokoh masyarakat lainnya untuk memilih dan menetapkan 1 (satu) calon anggota BPD yang akan diusulkan dalam musyawarah pada tingkat Rukun Warga (RW)

b. Musyawarah di tingkat RW, musyawarah ini dengan melibatkan calon anggota BPD yang telah terpilih dalam musyawarah di tingkat RT, pengurus RW serta tokoh masyarakat lainnya untuk menetapkan 2 (dua) calon anggota BPD yang akan diusulkan dalam musyawarah tingkat desa

c. Musyawarah di tingkat desa untuk menetapkan anggota BPD dengan melibatkan pemerintah desa, ketua RT, ketua RW, golongan profesi, tokoh masyarakat lainnya serta dihadiri oleh anggota BPD yang sudah diusulkan oleh masing-masing RW.

Hasil musyawarah pembentukan anggota BPD disampaikan oleh panitia BPD kepada BPD yang masih aktif untuk ditetapkan dalam keputusan BPD. Dalam melaksanakan tugasnya, panitia bertanggung jawab kepada BPD. Keputusan BPD tersebut disampaikan kepada Kepala Desa untuk diusulkan kepada bupati

\footnotetext{
12 Lihat pasal 4 Perda Sidoarjo Nomor 7 Tahun 2006 tentang Badan Permusyawaratan Desa.
}

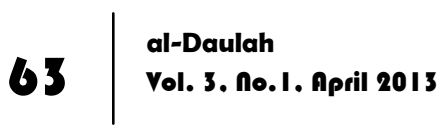


melalui camat untuk mendapatkan pengesahan dan Surat Keputusan (SK) anggota BPD. Masa jabatan anggota BPD adalah selama 6 tahun sejak pelantikan menjadi anggota BPD dan dapat diangkat lagi satu kali periode berikutnya. ${ }^{13}$

Setelah penetapan anggota BPD, anggota yang terpilih tersebut mengadakan rapat BPD secara khusus untuk membentuk struktur lembaga BPD dan memilih ketua BPD. Untuk rapat pemula, dipimpin oleh anggota BPD yang tertua dan dibantu dengan anggota BPD yang termuda. Pimpinan BPD dipilih dari dan oleh anggota BPD secara langsung. Pimpinan BPD terdiri dari 1 (satu) orang ketua, 1 (satu) orang wakil ketua, 1 (satu) orang sekretaris. ${ }^{14}$

Pasal 34 PP Nomor 72 Tahun 2005 Tentang Desa Juncto pasal 11 PERDA Sidoarjo Nomor 07 Tahun 2006 Tentang Badan Permusyawaratan Desa menyebutkan bahwa BPD memiliki dua fungsi utama, yaitu pertama, menetapkan peraturan desa bersama kepala desa dan kedua, menyalurkan aspirasi masyarakat.

Lembaga Badan Permusyawaratan Desa ini memiliki 6 wewenang yang harus dijalankan sesuai pasal 35 PP Nomor 72 Tahun 2005 tentang Desa Juncto pasal 12 PERDA Sidoarjo Nomor 07 Tahun 2006 tentang Badan Permusyawaratan Desa, antara lain: pertama, Membahas rancangan peraturan desa bersama kepala desa. Kedua, melaksanakan pengawasan terhadap pelaksanaan peraturan desa dan peraturan kepala desa. Ketiga, mengusulkan pengangkatan dan pemberhentian kepala desa. Keempat, membentuk panitia pemilihan kepala desa. Kelima, Menggali, menampung, menghimpun, merumuskan dan menyalurkan aspirasi masyarakat dan keenam, menyusun tata tertib BPD.

a. BPD Desa Jati

Desa Jati merupakan salah satu desa di Kecamatan Sidoarjo Kabupaten Sidoarjo. Desa Jati memiliki dua dusun, yaitu Dusun Babatan dan Dusun Jati. Luas wilayah Desa Jati

\footnotetext{
${ }^{13}$ Widarto, Wawancara, Sidoarjo, 26 Maret 2013.

${ }^{14}$ Wannur, Wawancara, Sidoarjo, 30 Maret 2013.
} 
140 Ha. Jumlah penduduk Desa Jati sesuai dengan laporan per tribulan yang tertanda pada bulan Maret 2013 adalah 10.363 jiwa, yang terdiri dari jumlah penduduk laki-laki 5.210 jiwa dan jumlah penduduk perempuan 5.153 jiwa. Desa Jati terdiri dari 41 Rukun Tetangga (RT) dan 8 Rukun Warga (RW). Sehingga, BPD di Desa Jati ini memiliki anggota BPD sebanyak 9 anggota pada periode 2007-2013. ${ }^{15}$

Pemerintahan Desa Jati sudah menjalankan peraturan yang berlaku yaitu PP Nomor 72 Tahun 2005 tentang Desa Juncto PERDA Sidoarjo Nomor 07 Tahun 2006 tentang Badan Permusyawaratan Desa dengan membentuk lembaga kemasyarakatan yaitu Badan Permusyawaratan Desa demi mewujudkan kesejahteraan masyarakat. Dalam melaksanakan tugas dan fungsinya BPD Desa Jati ini dari 6 (enam) tugas BPD, yang dijalankan hanya menjalankan 3 tugasnya yaitu Pertama, menampung dan menyalurkan aspirasi masyarakat. Kedua, mengusulkan pengangkatan kepala desa ketika masa jabatannya akan berakhir yang kemudian membentuk panitia pemilihan Kepala desa, ketiga menyusun tata tertib BPD. Dalam menampung dan menyalurkan aspirasi masyarakat juga kurang maksimal. Sedangkan tugas mengusulkan pemberhentian Kepala desa, membahas rancangan peraturan desa bersama dengan Kepala desa, melakukan pengawasan terhadap peraturan desa dan peraturan Kepala desa tidak dijalankan oleh lembaga tersebut. Padahal Kepala desa di desa Jati kurang lebih 3 tahun tidak aktif dalam menjalankan pemerintahan desa, lembaga BPD tidak ada musyawarah dengan masyarakat dan tidak mengusulkan pemberhentian. Waktu 3 tahun itu tidak singkat, masyarakat butuh akan pemimpin yang peduli terhadap rakyatnya, karena pemimpin tersebut dipilih langsung oleh masyarakat. 
BPD Desa Jati kurang menstimulus masyarakatnya agar bersifat kritis dan partisipatif, sehingga dalam penyelenggaraan pemerintah desa ini kurang menerapkan prinsip partisipasi dan demokratis, karena penyelenggaraan pemerintahan dan pembangunan desa harus mampu mewujudkan peran aktif masyarakat agar masyarakat senantiasa memiliki dan turut serta bertanggungjawab terhadap perkembangan kehidupan bersama sebagai sesama warga. Penyelenggaraan pemerintahan dan pelaksanaan pembangunan di desa harus mengakomodasi aspirasi masyarakat yang diartikulasi dan diagregasi melalui BPD dan lembaga kemasyarakatan yang lainnya sebagai mitra pemerintahan desa. ${ }^{16}$ Tujuan utama adanya lembaga BPD ini tidak lain untuk memberdayakan aspirasi masyarakat. Karena Pemberdayaan masyarakat merupakan penyelenggaraan pemerintahan dan pelaksanaan pembangunan di desa untuk meningkatkan taraf hidup dan kesejahteraan masyarakat melalui penetapan kebijakan, program dan kegiatan yang sesuai dengan esensi masalah dan prioritas kebutuhan masyarakat.

b. BPD Desa Banjar Bendo

Desa Banjar Bendo merupakan salah satu desa di Kecamatan Sidoarjo Kabupaten Sidoarjo. Desa Banjar Bendo memiliki 3 (tiga) dusun, yaitu dusun Dukuh, dusun Banjar Bendo dan dusun Banjar Poh. Luas wilayah desa Banjar Bendo 131,5 Ha. Jumlah penduduk desa Banjar Bendo sesuai dengan data monografi desa dan kelurahan adalah 8052 jiwa, yang terdiri dari jumlah penduduk laki-laki 4031 jiwa dan jumlah penduduk perempuan 4021 jiwa. Desa Banjar Bendo terdiri dari 38 Rukun Tetangga (RT) dan 8 Rukun Warga (RW).

${ }^{16}$ Imran, Wawancara, Sidoarjo, 30 Maret 2013. 
Sehingga, BPD di desa Banjar Bendo ini memiliki 9 anggota pada periode 2010-2016. ${ }^{17}$

BPD desa Banjar Bendo merupakan lembaga yang sangat aktif dan efekif dalam menjalankan tugas dan fungsinya, dari 6 (enam) tugas BPD, semuanya dilaksanakan dengan baik, seperti menampung dan menyalurkan aspirasi masyarakat. BPD ini selalu memprioritaskan suara rakyat demi kesejahteraan masyarakatnya. Tugas lainnya yaitu mengusulkan pengangkatan Kepala desa ketika akan habis masa jabatannya dan kemudian membentuk panitia pemilihan Kepala desa. Dalam waktu dekat ini anggota BPD membentuk panitia pemilihan Kepala desa, karena pada bulan Agustus ini akan ada pemilihan Kepala desa, sehingga anggota BPD aktif mengadakan pertemuan dengan masyarakat guna membentuk panitia, adapun susunan panitia tersebut murni dari masyarakat bukan dari anggota BPD dan perangkat desa. Tugas lainnya yaitu membahas rancangan peraturan desa bersama dengan Kepala desa. Bukti bahwa BPD benar-benar menjalankan tugas dan fungsi membentuk dan menetapkan Perdes yaitu dengan terbentuknya 3 produk hukum dalam tingkatan desa, antara lain Peraturan desa Nomor 4 Tahun 2012 tentang Penduduk Musiman (kontrak/kost) Serta Pelanggaran Kesusilaan (Tindak Asusila), Peraturan Desa Nomor 5 Tahun 2012 tentang Ijin Usaha, Ijin Keramaian, Ijin Pembangunan Bagi Penduduk Desa Banjar Bendo dan Belum Penduduk desa Banjar Bendo dan Keputusan Kepala Desa Banjar Bendo tentang Peraturan Pemakaman dan larangan membangun/mengkijing/mengeris di makam Islam dusun Banjar Bendo. ${ }^{18}$ Selain tugas-tugas yang tertera di atas, BPD juga mempunyai tugas melakukan pengawasan terhadap peraturan desa dan peraturan Kepala desa. Dari peraturan yang telah dibentuk tersebut sudah berjalan sebagaimana

${ }^{17}$ Sugeng Bahagia, Wawancara, Sidoarjo, 26 Maret 2013.

${ }^{18}$ Wannur, Wawancara, Sidoarjo, 30 Maret 2013.

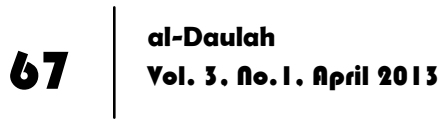


mestinya atau tidak. Jika terdapat warga yang melanggarnya maka BPD mengusulkan kepada perangkat desa agar orang yang melanggarnya akan dikenai sanksi sesuai tercantum pada peraturan tersebut. Sebagai anggota BPD yang aktif, maka BPD ini menyusun tata tertib BPD agar lembaga ini berlangsung secara efektif dan tanggung jawab.

c. BPD Desa sumput

Desa Sumput merupakan salah satu desa di Kecamatan Sidoarjo Kabupaten Sidoarjo. Desa Sumput memiliki dua dusun, yaitu dusun Sumput dan dusun Kedayon. Jumlah penduduk desa Sumput sesuai dengan data profil desa yang tertanda pada tahun 2012 adalah 4.494 jiwa, yang terdiri dari jumlah penduduk laki-laki 2.277 jiwa dan jumlah penduduk perempuan 2.217 jiwa. Desa Sumput terdiri dari 35 Rukun Tetangga (RT) dan 7 Rukun Warga (RW). BPD di Desa Sumput ini memiliki anggota BPD sebanyak 7 anggota pada periode 2007-2013. ${ }^{19}$

Lembaga BPD di desa Sumput ini dalam menerapkan fungsi dan tugasnya dari 6 (enam) tugas pokok BPD, yang dijalankan hanya menjalankan 4 tugasnya, pertama menampung dan menyalurkan aspirasi masyarakat. Kedua, mengusulkan pengangkatan Kepala desa ketika akan habis masa jabatannya. Ketiga, membentuk panitia pemilihan Kepala desa, dan keempat, menyusun tata tertib BPD. Adapun fungsi menetapkan peraturan desa bersama Kepala desa tidak dijalankan, padahal anggota BPD mempunyai hak untuk mengajukan rancangan peraturan desa yang akan dibentuk suatu peraturan desa (PERDES). Tetapi lembaga BPD di desa Sumput ini tidak pernah mengajukan rancangan peraturan desa sama sekali, bahkan pihak perangkat desa pernah mengajukan raperdes kepada lembaga BPD, tetapi tidak ada

${ }^{19}$ Profil Desa Sumput 2012. 
respon terhadap RAPERDES tersebut bahkan tidak ada tindak lanjutnya. ${ }^{20}$ Menurut sekretaris BPD, anggota BPD belum berani membentuk peraturan desa (PERDES) karena lembaga BPD ini belum memahami tentang cara pembentukan peraturan desa. Sehingga anggota BPD hanya menerapkan dan menjalankan peraturan desa yang sudah ada seperti Peraturan tentang Anggaran Pendapatan Belanja Desa (APBDes), Produk Pelepasan Tanah Gogol dan Rancangan Jangka Pendek Desa. Keluhan sekretaris BPD ini dalam menjalankan tugasnya yaitu tidak ada asosiasi (kumpulan) anggota BPD se-Kabupaten Sidoarjo agar bisa saling sharing dan mendapat masukan dari pihak kecamatan tentang kinerja Lembaga BPD. ${ }^{21}$ Tugas melaksanakan pengawasan terhadap pelaksanaan peraturan desa dan peraturan kepala desa juga tidak dijalankan.

Peranan BPD dalam Pemberdayaan Masyarakat Desa Kecamatan Sidoarjo Menurut PP No. 72 Tahun 2005 Juncto PERDA Sidoarjo Nomor 07 Tahun 2006 dalam Perspektif Fiqh Siyasah

Lembaga yang muncul dari perintah di dalam surat Ali-Imran ayat 159 tersebut dinamai shûrâ atau konsultasi atau dewan penasihat. Umat Islam berpendapat bahwa syûrâ merupakan perwujudan asli dari perwakilan atau pemerintahan konstitusional dalam Islam. Dalam praktik kehidupan umat Islam, lembaga yang paling dikenal sebagai pelaksana Shûrâ adalah ahl al-hall wa al-'aqd pada zaman al-Khulafa al-Rasyidin.

Secara harfiah, ahl al-hall wa al 'aqd berarti orang yang dapat memutuskan dan mengikat. Para ahli figh siyasah merumuskan pengertian ahl al-hall wa al 'aqd sebagai orang yang memiliki kewenangan untuk memutuskan dan menentukan sesuatu atas nama umat (warga negara). Dengan kata lain, ahl al-hall wa al 'aqd

20 M. Saichu Rofi'i, Wawacara, Sidoarjo, 22 Maret 2013.

${ }^{21}$ Arif Warta Wibawa, Wawancara, Sidoarjo, 30 Maret 2013.

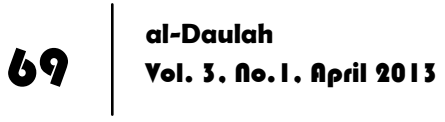


adalah lembaga perwakilan yang menampung dan menyalurkan aspirasi atau suara masyarakat. ${ }^{22}$

Istilah ahl al-hall wa al 'aqd di kalangan para ulama memiliki perbedaan penyebutan, Ibnu Taimiyah menyebutnya dengan ahl al-shawkah, yaitu lembaga perwakilan yang menampung dan menyalurkan aspirasi atau suara masyarakat. ${ }^{23}$ Ahl al-hall wa al 'aqd juga disebut oleh al-Mawardi sebagai ahl al-ikhtiyar, yaitu golongan yang berhak memilih. ${ }^{24}$ Istilah yang lebih populer dipakai pada awal pemerintahan Islam tentang hal ini adalah ahl al-shûrâ. Semuanya mengacu pada pengertian "sekelompok anggota masyarakat yang mewakili umat dalam menentukan arah dan kebijaksanaan pemerintahan demi tercapainya kemaslahatan hidup mereka". ${ }^{25}$

Anggota ahl al-hall wa al 'aqd dapat dipilih melalui beberapa cara, seperti yang pernah dicontohkan oleh Rasulullah. Namun, seiring dengan perkembangan zaman mekanisme itu telah mengalami kolaborasi, khususnya dengan pemikiran barat. Anggota ahl al-hall wa al 'aqd dapat dipilih melalui beberapa mekanisme, diantaranya dengan: ${ }^{26}$

a. Pemilihan umum atau pemilu.

b. Seleksi.

c. Pengangkatan secara langsung dengan sistem berurutan

Pemerintahan Umar bin Khattab dalam pemilihan ahl al-hall wa al-'aqd tidak melewati pemilu dengan melihat suara terbanyak dari kaum muslimin atau dengan cara penobatan langsung oleh rasul atau khalifah. Namun, saat itu dengan cara pemilihan spontan yang secara alami disaring oleh realita hidup masyarakat

\footnotetext{
22 Muhammad Iqbal, Fiqih Siyasah Kontekstualisasi Doktrin Politik Islam, I38.

${ }^{23}$ Sariono, "Ahl al-Hall wa al-'Aqd", dalam http://refrensiagama.com/201 I/0 I/ahl-al-hall-wa-alaqd.htm

${ }^{24}$ Farid Abdul Khaliq, Fikih Politik Islam, 79.

${ }^{25}$ Muhamad iqbal, Fiqh Siyasah, 138.

${ }^{26}$ Imam Al Mawardi, Al-Ahkam As-shulthaniyyah fi al-Wilaayah ad-Diniyyah, Penerjemah: Fadli Bahri, (Jakarta: Darul Falah, 2006), I8- 19.
} 
yang melihat dari sisi pemahamannya terhadap agama, kecerdasaannya dan keutamaannya. ${ }^{27}$

Rakyat diwajibkan untuk memilih segolongan dari mereka, yaitu orang-orang yang khusus dari ahl al-hall wa al-'aqd yang mempunyai sifat-sifat yang harus ada pada mereka seperti berilmu yang dapat membantunya untuk memikirkan perkara-perkara umum dan urusan-urusan politik, berkemampuan untuk mengeluarkan keputusan dan undang-undang yang dapat mewujudkan kemaslahatan rakyat, juga berkemampuan untuk melakukan kewajiban pengawasan atas wewenang dewan eksekutif, baik pemerintah dan penguasa, demi mencegah kemungkaran yang mungkin akan dilakukannya sebagai tindakan pelanggaran terhadap hak-hak Allah, demi menjaga hak dan kebebasan. Oleh karena itu peran lembaga Badan Permusyawaratan Desa di desa Jati, desa Banjar Bendo dan desa Sumput Kecamatan Sidoarjo dilaksanakan secara musyawarah.

Sistematika pemilihan anggota BPD sama dengan pemilihan ahl al-hall wa al-'aqd melalui mekanisme seleksi yaitu masyarakat dapat memberikan penilaian terhadap orang-orang yang mempunyai kemampuan dan perhatian besar pada masalah kemaslahatan umat. Hal ini sejalan dengan pemilihan anggota BPD di desa Jati, desa Banjar Bendo dan desa Sumput Kecamatan Sidoarjo menurut PERDA Sidoarjo Nomor 07 Tahun 2006 tentang Badan Permusyawaratan Desa yaitu dengan cara penjaringan dan penyaringan masyarakat secara bertingkat, yaitu melalui pertama musyawarah di tingkat Rukun Tetangga dengan melibatkan seluruh Kepala Keluarga, unsur tokoh masyarakat lainnya untuk menetapkan calon anggota BPD yang akan diusulkan dalam musyawarah tingkat Rukun Warga, kedua musyawarah di tingkat Rukun Warga dengan melibatkan calon anggota BPD hasil musyawarah tingkat RT, pengurus RW dan tokoh masyarakat lainnya untuk menetapkan calon anggota BPD yang akan

\footnotetext{
${ }^{27}$ Farid Abdul Khaliq, Fikih Politik Islam, 79.
}

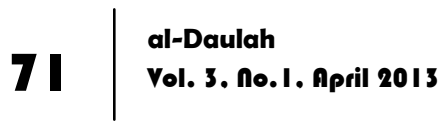


diusulkan dalam musyawarah tingkat desa, ketiga musyawarah di tingkat desa untuk menetapkan anggota BPD dengan melibatkan pemerintah desa, ketua RW, golongan profesi dan tokoh masyarakat lainnya, serta dihadri oleh calon anggota BPD yang diusulkan oleh masing-masing RW.

Anggota BPD dalam merealisasikan peranannya ditelisik dari perspektif figh siyasah, maka peran, kewenangan dan tanggung jawabnya BPD sesuai dengan peran dan kewenangan ahl al-hall wa al-'aqd yaitu pertama, pemegang kekuasaan tertinggi yang mempunyai wewenang untuk memilih dan membaiat imam. Kedua, mengarahkan kehidupan masyarakat kepada yang maslahat. Ketiga, membuat undang-undang yang mengikat kepada seluruh umat di dalam hal-hal yang tidak di atur secara tegas dalam al-Qur'an dan Hadis. Keempat, tempat konsultasi imam di dalam menentukan kebijakannya. Dan kelima, mengawasi jalannya pemerintahan.

Adapun peranan BPD di desa Jati, desa Banjar Bendo dan desa Sumput jika ditinjau dari perspektif figh siyasah, adalah sebagai berikut:

1. BPD Desa Jati

BPD desa Jati ini kurang aktif dalam menjalankan tugas dan fungsinya, dari 6 (enam) tugas pokok BPD, yang dijalankan hanya menjalankan 3 tugasnya yaitu: Pertama, menampung dan menyalurkan aspirasi masyarakat. Kedua, mengusulkan pengangkatan Kepala desa ketika masa jabatannya akan berakhir yang kemudian membentuk panitia pemilihan Kepala desa, ketiga menyusun tata tertib BPD. Dalam menampung dan menyalurkan aspirasi masyarakat juga kurang maksimal. Sedangkan tugas mengusulkan pemberhentian Kepala desa, membahas rancangan peraturan desa bersama dengan Kepala desa, melakukan pengawasan terhadap peraturan desa dan peraturan Kepala desa tidak dijalankan oleh lembaga tersebut. Jika ditinjau dalam figh siyasah lembaga ahl al-hall wa al-'aqd ini tidak menjalankan 
tugasnya membuat undang-undang yang mengikat kepada seluruh umat serta mengawasi jalannya pemerintahan.

2. BPD Desa Banjar Bendo

BPD desa Banjar Bendo merupakan lembaga yang sangat aktif dan efekif dalam menjalankan tugas dan fungsinya, dari 6 (enam) tugas pokok BPD, semuanya dilaksanakan dengan baik yaitu pertama menampung dan menyalurkan aspirasi masyarakat. BPD ini selalu memprioritaskan suara rakyat demi kesejahteraan masyarakatnya. Kedua, mengusulkan pengangkatan Kepala desa ketikan akan habis masa jabatannya dan Ketiga membentuk panitia pemilihan Kepala desa. Keempat, membahas rancangan peraturan desa bersama dengan Kepala desa. Kelima, melakukan pengawasan terhadap peraturan desa dan peraturan Kepala desa. Keenam, menyusun tata tertib BPD agar lembaga ini berlangsung secara efektif dan tanggung jawab. Jika ditinjau dalam figh siyasah lembaga ahl al-hall wa al-'aqd ini menjalankan semua tugas dan fungsinya.

3. BPD Desa sumput

Lembaga BPD di desa sumput ini dalam menerapkan fungsi dan tugasnya kurang aktif, karena dari 6 (enam) tugas pokok BPD, yang dijalankan hanya menjalankan 4 tugasnya, pertama menampung dan menyalurkan aspirasi masyarakat. Kedua, mengusulkan pengangkatan Kepala desa ketika akan habis masa jabatannya. Ketiga, membentuk panitia pemilihan Kepala desa, dan keempat, menyusun tata tertib BPD. Jika ditinjau dalam figh siyasah lembaga ahl al-hall wa al-'aqd ini tidak menjalankan tugasnya membuat undang-undang yang mengikat kepada seluruh umat serta mengawasi jalannya pemerintahan.

Menurut penulis sesuai dengan hasil penelitian, salah satu peran BPD yang paling penting yaitu membentuk peraturan desa 
bersama Kepala desa. Karena desa yang sudah dibentuk harus memiliki landasan hukum dan perencanaan yang jelas dalam setiap aktivitasnya. Dalam proses pembentukan perdes ini hanya dari wakil-wakil rakyat (Lembaga BPD) bersama Kepala desa. Dalam melaksanakan prinsip musyawarah ini tidak mungkin dilakukan dengan cara melibatkan seluruh umat secara langsung, tetapi yang paling memungkinkan menurut logika adalah seorang pemimpin bermusyawarah dengan umatnya melalui wakil-wakil mereka yang telah dipilih oleh umat (ahl al-hall wa al-'aqd).

\section{Penutup}

Peranan Badan Permusyawaratan Desa (BPD) dalam memberdayakan masyarakat desa Kecamatan Sidoarjo menurut PP Nomor 72 Tahun 2005 Juncto PERDA Sidoarjo Nomor 07 Tahun 2006 tentang Badan Permusyawaratan Desa, bahwa BPD yang aktif menjalankan tugas dan fungsinya yaitu BPD Desa Banjar Bendo karena sudah menjalankan semua tugas dan fungsinya, sedangkan BPD yang kurang aktif dalam menjalankan tugas dan fungsinya yaitu BPD desa Jati dan BPD desa Sumput, karena dari 6 tugas dan fungsinya yang dijalankan hanya beberapa saja seperti menampung dan menyalurkan aspirasi masyarakat, mengusulkan pengangkatan kepala desa ketika masa jabatannya akan berakhir yang kemudian membentuk panitia pemilihan Kepala desa serta menyusun tata tertib BPD.

Peranan Badan Permusyawaratan Desa di desa Kecamatan Sidoarjo menurut PP Nomor 72 Tahun 2005 tentang Desa Juncto PERDA Sidoarjo Nomor 07 Tahun 2006 tentang Badan Permusyawartan Desa ditinjau dari figh siyasah adalah sejalan dengan lembaga ahl al-hall wa al-'aqd dari sudut pandang kedudukannya sebagai lembaga legislatif. Ditinjau dalam figh siyasah BPD desa Banjar Bendo telah menjalankan tugas dan fungsinya sesuai dengan tugas ahl al-hall wa al-'aqd, adapun BPD desa Jati dan BPD desa Sumput dalam menjalankan tugas dan 
fungsinya tidak menjalankan tugas ahl al-hall wa al-'aqd yang membentuk undang-undang.

\section{Daftar Pustaka}

Ashshofa, Burhan. Metode Penelitian Hukum. Jakarta: PT Rineka Cipta, 2004.

Buraey (al-), Muhammad. Penerjemah: Ahmad Nashir Budiman,

Islam: Landasan Alternatif Administrasi Pembangunan. Jakarta:

Rajawali, 1986.

Departemen agama RI. Al-Qur'an Terjemah al-Jumatul Ali. Bandung:

CV Penerbit J-ART, 2005.

Iqbal, Muhammad. Fiqih Siyasah: Kontekstualisasi Doktrin Politik Islam. Jakarta: Gaya Media, 2001.

Khaliq, Farid Abdul. Fikih Politik Islam. Jakarta: AMZAH, 2005.

Mawardi (al-), Imam. Al-Ahkam As-shulthaniyyah fi al-Wilaayah ad-

Diniyyah. Penerjemah: Fadli Bahri, Jakarta: Darul Falah, 2006.

Sumadi, Suryabrata. Metodologi Penelitian. Jakarta: PT Raja Grafindo Persada, 2004.

Wijokusumo, Iskandar dan Soemardji Ansori. Metode Penelitian

Kualitatif: Bidang Ilmu-ilmu Sosial Humanoria (Suatu Pengantar).

Surabaya: Unesa University Press, 2009.

Peraturan Pemerintah Nomor 72 Tahun 2005 Juncto Pasal 11 Peraturan Daerah Sidoarjo Nomor 07 Tahun 2006.

Undang-undang Nomor 32 Tahun 2004 Tentang Pemerintahan Daerah.

Kurnia, Nuraida Muji. "Peran Badan Permusyawaratan Desa (BPD) Sebagai Organisasi Sektor Publik", dalam http://djangka.com/2013/01/24/peran-badan-

permusyawaratan-desa-bpd-sebagai_organisasi-sektorpublik/.

Sariono. "Ahl al-Hall wa al-'Aqd", dalam http://refrensiagama.com/2011/01/ahl-al-hall-wa-al-aqd.htm. 
Walhi. "Perdes (Penting bagi Masyarakat dalam Menentukan Arah Pembanguna Desa)", dalam http://www.walhibengkulu.org/2009/06/perdes-penting-bagimasyarakat dalam.html. 